\title{
Infusing an international online learning experience into the curriculum: a United States and Mexico collaboration
}

\author{
Infundindo uma experiência de aprendizagem internacional online no \\ currículo: uma colaboração entre Estados Unidos e México
}

\begin{abstract}
Flavia Iuspa
Received her Ed.D. in Curriculum and Instruction with specialization in International and Intercultural Education from Florida International University. Instructor an Director of the Master of Science in Curriculum and Instruction (MSCI). Florida - EUA

iuspaf@,fiu.edu
\end{abstract}

\begin{abstract}
Globally competent people have the knowledge, skills, and dispositions to understand and to find lasting solutions to global issues and problems using multiples perspectives. They understand interdependence and interconnectedness of the global systems, cultures and communicate effectively with different people around the world. The purpose of this paper is to discuss how an international online learning experience enhances our awareness of different perspectives and cultural diversity, the challenges facing humanity and the world, and our role as globally competent citizens. In particular, this paper discusses the design and implementation of an international online learning experience to promote global learning between two higher education students in the United States and Mexico. The paper uses global competency as the pedagogical framework for teaching and promoting global learning within the context of global competency.

Key Words: Global Competence. Global Learning. Online Learning. Multicultural Online Collaboration. International Cooperation in Higher Education. Cross-Border Delivery of Education.
\end{abstract}

Resumo: Pessoas globalmente competentes têm o conhecimento, as habilidades e as disposições para entender e encontrar soluções duradouras para problemas e problemas globais usando perspectivas múltiplas. Elas entendem a interdependência e interconexão dos sistemas globais, culturas e se comunicam efetivamente com pessoas diferentes em todo o mundo. O objetivo deste artigo é discutir como uma experiência internacional de aprendizado online aumenta nossa consciência sobre as diferentes perspectivas e diversidade cultural, os desafios que a humanidade e o mundo enfrentam e nosso papel como cidadãos globalmente competentes. Em particular, este artigo discute a elaboração e implementação de uma experiência de aprendizado online internacional para promover a aprendizagem global entre estudantes do ensino superior nos Estados Unidos e no México. O artigo considera a competência global como estrutura pedagógica para ensinar e promover a aprendizagem global dentro do contexto da competência global.

Palavras-chave: Competência Global. Aprendizagem Global. Aprendizagem Online. Colaboração Multicultural Online. Cooperação Internacional em Educação Superior. Difusão Transfronteiriça de Educação. 


\section{Introduction}

Global education seen as a curriculum provides the content and strategies for global learning. Global knowledge, skills and understanding are needed to engage people especially young learners in the effort to make the world a better place. Collaborative online learning is becoming a legitimate way of teaching global learning. As the global community becomes more open and transparent and racial, ethnic, cultural, economic and political conflicts escalate around the world, there is a need to find a modality for global expression.

The deepening global diversity within nations highlights the world's complexity and interdependence among nations. At the same time, a current backlash against globalization and the rise of nationalism, more than ever presents to higher education institutions the need to provide to students the ability to engage in meaningful engagement experiences with other cultures and perspectives. Global learning, defined as the process of diverse people collaboratively analyzing and addressing complex problems that transcend borders (LANDORF; DOSCHER, 2015), embodies international collaboration and engagement to address global challenges.

Global Learning promotes critical and reflective discourse and the engagement of simple and complex dialogue, which often leads to practical and structural action at the local, national, regional, and global levels (ABDULLAHI, 2010). Pike and Selby (1995) proposed four-dimensional model of global learning: spatial, issues, temporal, and inner dimensions. In the spatial dimension, concepts such as interdependence and interconnectedness at multiple levels including intrapersonal, interpersonal, international, regional and local issues and problems are explored. In the issues dimension, the focus is on key global issues, problems, and themes. In the temporal dimension, the focus on giving the future the central place in the educational discourse and process. In the inner dimension, the examination and reexamination of self and relationship with others are explored within the context of selfidentity, self-knowledge and self-discovery (ABDULLAHI, 2010). Collaborative online learning offers the opportunity to students in different countries and cultures to learn quickly about issues and problems impacting people and endangering the planet. The purpose of this paper is to discuss the implementation of international online learning experience between an American and Mexican universities to enhance cross-cultural awareness; a key disposition for global learning. The paper uses global competency as the pedagogical framework for teaching and promoting global learning. The purpose guided the paper research question: How does an international online learning experience enhances global competences? 


\section{International Online Learning and Global Competence}

Many universities and colleges in the United States and around the world are developing centers and institutes to provide a platform for engagement, activism, advocacy, partnerships, and international collaboration. The international online learning experience provides a more intensive, friendly, and innovative environment to design a curricular internationalization effort through the use of online technology. International online experience "encourages and supports the development and implementation of collaborative online international courses as a format for experiential cross-cultural learning" (SUNY, Guide for Course Development, 2017, p. 1). It seeks to build bridges between study abroad, instructional design, and teachers through team-taught courses, and in the process, it promotes, integrates, and enhances international, intercultural education, (global education, education for global citizenship) experiences across curricula (SUNY, Guide for Course Development, 2017, p. 1)

Consensus has been reached today about the need for students to develop global competency to face the challenges facing the 21st century (Partnership for 21st Century Learning, 2014; OECD, 2016). Global competence is defined as a disposition, "a way of thinking and doing and as a value" (REIMERS et. al., 2016, p. xxxii). Global Competence promotes a lifelong learning and inquiry based attitude, directed to not only promoting the understanding of the local and global issues relationship, but also to engaging students in working to find solutions to global challenges. Having a global competence, thus, embraces a disposition to inquire about the world (for example, engaging with questions of significance, exploring local-global connections, and seeking information beyond familiar environments). Boix-Mansilla (2016) described three dispositions global thinkers should have:

1) A disposition to understand multiple perspectives—others' and their own.

2) A disposition toward respectful dialogue (communicating across difference appropriately, listening generously, and sharing courageously).

3) A disposition toward taking responsible action (being inclined to see and frame opportunities to improve conditions, collaborating with others, and mobilizing themselves to act) (p. 13).

The international online experience, as a content and a global pedagogical framework, promotes cross/multicultural understanding between students in different countries through online collaboration. In the context of online collaboration, Law and 
NguyenNgoc (2010) discussed three dimensions: social, cognitive and affective. These dimensions are designed to influence the quality of cross-cultural interaction. It is important to recognize that these dimensions are not only aligned with the dispositions of global competence, but are also embedded in what the international online experience concept represents. The international online experience framework enhances students' social (crosscultural communication interaction), the cognitive (through the analysis of content area through different lenses), and the affective (through self-reflection and online discussion cross-culturally) fostering a holistic disposition toward global thinking and competence. Furthermore, it exemplifies a pedagogy for a global learning and the internationalization of the curriculum (ALTBACH; KNIGHT, 2007; IUSPA, 2014).

\section{International online experience Pre and Instructional Planning}

The international online experience was infused into the cross-listed courses Developing a Global Perspective (SSE 4380 and SSE 5381) offered at an university in south Florida, United States and an undergraduate course (INR 4XXX) at Universidad de Chihuahua, México, as part of their pedagogical international activities.

The involvement with the international online experience started during the summer term of 2016, when the American university was invited to participate in the US-Mexico Multistate international online experience Program (MCP). The program was an eye opener and rich in global content and curricular design. The goal of the program was to "increase inter-university collaboration between Mexican and US academic institutions through international online experience-enhanced courses that link students, professors, and staff, contributing to greater intercultural understanding and cross-border dialogue" (SUNY Website, para. 1). The professional development program provided a 180 hours of professional development. This online program offered in four phases (as well as a workshop in Mexico), led the participants from a gradual learning path of what international online experience is, to the matching and selection of universities partners between the US and Mexico, and more course specific international online experience planning and development between the US and Mexico partners.

The university partner in Mexico was a public higher education institution. From the start, the instructors developed a close working relationship and were committed to the design of a rewarding international online experience for our students. After several online meetings, discussions, and reflections on how to infuse and harmonize an international 
online experience for our respective students, the instructors decided to focus on the student learning outcome (SLO): Students will develop awareness of US and Mexico perspectives on global issues. The instructors collaboratively selected the content from a variety of articles related to the following global issues: Population Trends in the 21st Century, Climate Change, and Terrorism. The instructors decided to select these topics given the similarity in content in both courses.

After the pre-instructional planning, the instructors engaged in the instructional planning of the international online experience. The seven weeks' modules were developed and delivered through the Learning Management System (LMS) schoology. Schoology allowed students and professors from both universities to have access to a content without being restricted by the respective universities' student access to blackboard or moodle. The instructors worked together on the international online experience modules' set up (incorporating resources and activities instructions) as well as instructors' introduction video.

\section{International online experience Strategies and Activities}

The international online experience was offered to the respective US and Mexico students during the Spring 2017. The international online experience was 7 weeks long during which students were engaged in the cross-cultural analysis and discussion of global issues. The rationale for the international online experience cross-cultural online activities was that they "must provide opportunities for dynamic and reciprocal communication, interactions, and collaborations that facilitate knowledge co-construction" (CHEN; CAROPRESO; HSU; YANG, 2012, p. 25) among the students. The activities were developed in relations to the three dispositions of developing global competency: 1) recognition of multiple perspectives, 2) respectful dialogue, and 3) responsible action.

The seven weeks international online experience design model is as follows: International online experience Week 1 Introductions - Feb. 6 - 12, 2017. The purpose of international online experience week 1 activity was to help the international online experience US-Mexico students to recognize and appreciate likenesses/similarities and differences in people. To achieve this, the students were distributed in groups of 9 members (from the US and Mexico) to start working on Venn Diagram Get to know Each Other activity. This activity required each team to: 
1) with their international online experience US-Mexico Team members decide on three ways in which they were all alike (writing) those things in the intersecting areas of the diagram),

2) Include an image the represents who you are as a group, and

3) Each international online experience US-Mexico Team members must write in his or her circle three facts that are unique to him or her, as well as an image the represents who you are individually.

4) Finally, as a group develop the group's five golden rules/guidelines for communication within the group and with other international online experience USMexico Teams.

5) Each team was asked to upload its Venn-Diagram in the Venn Diagram Get to know Each Other discussion forum for the rest of the class to review and respond.

International online experience Week 2 - Feb. 13 - 19, 2017 and Week. 3 - Feb. 20 - 26, 2017. The purpose of international online experience week 2 and 3 was to examine demographics trends in the $21^{\text {st }}$ century and focus on Climate Change. These two topics were discussed together due to the link between population growth and climate change. Activities were divided as part 1 due on week 2 , and part 2 due on week 3 .

Week 2 part 1 activity required students to read two articles, one addressing population trends and the other one on climate change, and answer the prompt questions as a group:

1- What are the main points/ideas of the readings?

2- How are both readings related to each other?

3- What are some (minimum two) different US-Mexico perspectives that emerged from your US-Mexico international online experience team discussions of the two global issues?

To answer the questions, US- Mexico international online experience teams were required to meet synchronously (either through skype, adobe connect, or any tool of your choice) to discuss the readings and the possible answers to the questions. The synchronous meeting had a 30 minutes minimum requirement, and should be recorded. The recorded link for the meeting submitted to the professors under week 2 discussion forum together with group's word document answering the questions. 
Week 3 part 2 continued the discussion on population trends and the climate but more specifically to the US and Mexico. Each US- Mexico international online experience team was to:

1. Develop a table highlighting the different US-Mexico perspectives that emerged on the global issues of demographics trends and climate change.

2. Identify one image (picture, photograph, icons, drawing, etc.) that represents/summarize/captures both perspectives for each global issue.

3. Develop a 6 minutes maximum reflective video where they would explain a) why you choose that image and how the image relates to the US and Mexico perspectives, and b) how the image (you may have a different image if your $1^{\text {st }}$ image does not represent your team's interactions) relates to the way the group interact it taking into account the different backgrounds.

4. Upload the US-Mexico international online experience team video under week 3 discussion forum for the professors and classmates to watch and comment on.

International online experience Week 4 - Feb. 27 - March 5, 2017. The purpose of the international online experience week 4 was to discuss the transnational phenomenon of Terrorism. During this week, students worked on:

1. Developing at least three questions based on the readings to foster further understanding/discussions of the readings.

2. One member of the US-Mexico team would post the questions on the discussion board. Each US Mexico team should start a new thread.

3. Each group was asked to post the questions by Thursday so the class and instructors would have until Sunday to respond to at least one question from each US- Mexico team.

International Online Experience Weeks 5 and 6 Final Project. The purpose of week 5 and 6 was for the students to work and present on the final international online experience project based on the international online experience' Student Learning Outcome (SLO): Develop awareness of different perspectives on global issues. The students' awareness in this respect would be reflected in their ability to recognize, discuss, and identify the different US and Mexico perspectives on global issues. The Advisory Role Project consisted on the following: Project Scenario 
Given what you know now and the possible changes in US international policy, You and your US - Mexico team are advisors to a non-profit organization advocating for both nations to work together on a global issue of your choice (ex: human rights, immigration, trade, etc).

\section{Project Task}

Each group was required to develop/create a 6 min max video or PowerPoint with recorded audio. In this task, each group's awareness on different perspectives was to be reflected in their ability to:

1. Identify the historical perspective of the US and Mexico on the global issue.

2. Name and compare the pros and cons of the different perspectives (keeping in mind the US change in Administration).

3. Come up with one recommendation on how both nations can work together on that global issue despite of the different perspectives.

Finally, students were asked to complete a self-reflection self-essay. In this essay, we asked the students to reflect on the questions: 1) What challenges did you encounter while you were working on the final project?, 2) How did you solve them or What steps did you take to solve them?, 3) What was especially satisfying to you about the process or the finished product?, and 4) What did you learn about yourself as you worked on the final project?

\section{Lessons learned}

Implementing international online experience in the classrooms is a transformative experience worth taking. The instructors started the journey with the goal to present to our students a valuable cultural learning experience. From the 7 weeks journey, learning took place at the faculty and students level.

As a faculty, our goal was to design a learning environment where content and cultural awareness would not conflict with each other. Thus, our fall 2016 semester planning led to a very structured international online experience. However, the faculty quickly learned that for all the planning the instructors have done, students experienced some challenges in the following areas:

More time to get to know each other. Based on the students feedback, the one week given to them to get to know each other was not enough. Students in both classrooms, felt rushed to get 
to know each other. Students perceived this activity as the first activity to worked on. In a sense, the students focus on completing the assignment rather than in the interaction itself to get to know each other.

For example, some students stated:

While I was working on activity 1 part 1 , some of the challenges I encountered was effective communication with group and being positive with one another. This challenge occurred when the assignment was close to being due and people were getting anxious to make sure that it was submitted on time. The time difference was where the confusion was coming from.

While working in activity one, a major challenge was to agree on a day and an hour with eight people to do the video conference.

While working on activity 1 part 1 , the real challenge was trying to come together as a team to meet online and discuss. I found that to be a challenge because I was at work, others had to miss class, and time changes interfered. As a team, we were still able to come together and have the meeting. I was able to attend the meeting while working. I was unable to use the video or microphone to speak due to the nature of my job. I was, however, able to hear the discussion and write a comment. I was very satisfied with the finished product because it shows the U.S. and Mexico international online experience team's perspectives about different issues in a concise and easy to understand manner.

Source: the author

Upon reflection from the students' feedback, the instructors decided to include a week before the start of the international online experience, a one-hour adobe connect meeting between both classrooms. The instructors decided to do this to 1) first address both classes at the same time and go over via face-to-face the expectations towards the experience, and 2) to allow the students to start building a sense of learning community. This is meant to bring an added value of networked interactions promoting an initial cultural, linguistic, interpersonal, and motivational development among the students (CANTO; JAUREGI; VAN DEN BERGH, 2013), and their own global competencies.

The instructors also decided to expand the getting to know each other activities from one week to two weeks. During the 1st week, the students, as a class, will work on the getting to know each other through the Social Lounge Discussion Forum. To do this, each student would be asked to post a 10 seconds snapshot addressing: 1) his/her name, 2) country of 
origin, and 3) his/her favorite place on earth (and why?), and asked to review and comment on at least two classmates. During the second week, students would work with their assigned teams on the Getting to Know Each Other Activity Venn Diagram and the group's golden rules of communication.

\section{International Online Learning and Global Learning}

The international online learning activities were designed to foster in students a high level of interaction between both cultures. The variety of activities from discussions forums, videos creation, synchronous and asynchronous meetings required each student to leave their comfort zone and approach the activities with a level of creativity and openness to new perspectives. The activities underlying factor was that students cross-cultural engagement would promote communication with sensitivity to multiple perspectives (OECD, 2016) as well as the dispositions needed to be a global citizen as described by Boix-Mansilla and Jackson (2011).

The final project, the Advisory Role Project, presented to the students the scenario that each group was part of an advocacy, non-profit organization whose task was to present the US and Mexico's perspective on the global issue of their choice, and present a recommendation for both nations to work together. The final project presented to the US and Mexican students a pedagogical task of active engagement to complete, where group participation and communication was a key element of the project delivery. At same level, both instructors expected that communications challenges will emerge given the language difference. Cross-cultural communication was the factor that students talked about on their reflections:

It was challenging to be separated and not know the progress other group members were making

on the project. When we hadn't talked for a few days, it was impossible to know if others were still

working on the project, or if they were focusing on something else. When we were able to get in

touch and communicate our research/voice notes via e-mail, I felt reassured about our progress. 
In the final project there were a couple of difficulties to choose the topic, but we finally decided terrorism and I had to help with the voice notes since my classmates have more difficulties with English language.

We encountered a lot of issues when dealing with our final project. ... We had a huge issue with communicating who was going to turn it in, so that made our submission late.

The biggest challenge I encountered while working on this project was by far communication.

Working with students with very busy schedules in different time zones was quite challenging, but it made the finished product all that much rewarding.

We created a Whatsapp group to communicate and it allowed for everybody to see comments and messages at their own leisure.

Source: the author

As part of the self-assessment, students were asked at the end of the international online experience if the participation in this activity has helped them to re-define their definition of a global citizen, and if they still consider themselves a global citizen. The students' responses articulated that the international online experience had given them a certain understanding of their own global citizenship concept.

Below are some responses from the students' about global citizenship:

For a long time, I thought that a global citizen is a person who can live in different parts of the world, who speaks more than one language and who has friends in various regions of the world. After the international Online Learning experience, I realized that just meeting people and traveling does not make a person global citizen. I learned that a global citizen is an individual who takes the time to learn, respect and have empathy for other cultures. A global citizen is a person who is open to change and has an unbiased perspective on the global problems that our planet carries.

The ... experience allowed me to realize that being a global citizen is much more than knowing and understanding what is going on in the world. Being a global citizen to me now means communicating with others, sharing each other's thoughts and questions, regarding the issues effecting the world. Being able to understand that an issue in one part of the world will eventually effect you in another part of the world. After this international online experience, I consider myself a global citizen because 
\begin{tabular}{l} 
I was able to share my thoughts, thinking, and questions about global issues with \\
individuals from another country. I learned their perspective and they learned my \\
perspective. \\
\hline The ... experience affirmed my definition of a global citizen: an intentional \\
participant in global society who considers factors beyond my immediate \\
environment and experience. The international online experience let me hear \\
firsthand the environment and experiences of others and I still consider myself a \\
global citizen". \\
\hline The ... experience made me realize how difficult it is to communicate with others. \\
It takes plenty of patience to understand other's perspective as well to adapt to how \\
they get things done. I believe this is part of being a global citizen. I believe I have \\
refined my skills in global citizenship, but I still have a long way to go.
\end{tabular} Source: the author

Group work and number of students in the groups. Joining two courses and setting groups was another challenge. In order to promote better interaction among students, the students were placed in groups with members from the US and Mexico. To accommodate all students, the international online learning experience ended up with 5 groups of 9 students in each. The large number of students in the groups did not facilitate the getting together and work as a group. Issues such as time and/or schedule conflicts emerged quickly within the groups.

Capdeferro, Romero \& Margarida (2012) stated in their study on online learners and online collaboration that the reasons leading to online students learning frustrations are: “(a) imbalance in the level of commitment, responsibility, and effort, b) unshared goals and difficulties in organization, c) difficulties in communication/dialogue in terms of frequency, d) imbalance in quality of individual contributions, e) conflict and problems in reaching consensus; f) imbalance between individual expected mark and group mark" (p.32). The instructors recognized that the students experienced some of these frustrations while working on the assignments given the number of students in the groups and the added factor of cultural communication.

The students highlighted a key reflective point to improve the international online experience. By decreasing the number of students in the groups to no more than 6 ( 3 from each side), students will have the opportunity to engage in synchronous "videocommunication that are more static, present visual cues (facial expressions, body language, 
laughter), and play a crucial role in the exchanges intensifying and clarifying meaning and contribute to enhance interpersonal relationships" (CANTO; JAUREGI; VAN DEN BERGH, 2013, p. 86), and decrease the level of frustration online cross-cultural collaboration may bring.

International Online Experience and Overall students reactions. The instructors designed the international online learning experience with the learning objective: "Students will develop awareness of US and Mexico perspectives on global issues". The learning outcome aligns to the three dispositions of developing global competency: 1) recognition of multiple perspectives, 2) respectful dialogue, and 3) responsible action. The overall assessment of the students of the international online learning experience was welcoming and reinforced the course' learning outcomes:

I liked getting to meet new people from a different country. Getting to hear other opinions about America was more eye opening that I already knew it was. Stereotypes, although sometimes done with realizing it are wrong most of the time.

Communication Time difference Experience

Working together with my country's team (we were more united than in past projects)

Hearing the opinion of students from another country --Talking about global issues from more than one perspective

Teamwork work with people from other country practice the English

Teamwork. Cooperation. Hard work.

Source: the author

\section{Conclusion and implications for future practice}

Students in both the US and Mexico engaged in dialogue about global issues and problems and worked together to offer possible solutions. For a period of seven weeks, students engaged in a cross-cultural collaborative learning experiences, a global pedagogy tool, that provided students in both countries a learning environment to explore, compare and contrast global issues perspectives between the US and Mexico. As a result, new insights and deep understanding of cross-cultural perspectives and communication emerged.

The international online learning experience enhanced and reinforced the key dispositions of global competences of understanding multiple perspectives-others' and 
their own, respectful dialogue across cultures, and taking responsible action (BOIXMANZILLA; JACKSON, 2011; BOIX-MANZILLA, 2016). As the students engaged in the international online cross-cultural projects, students from the US and Mexico share a space for dialogue and action. This experience promoted an experimental learning beyond just the prescriptive content knowledge.

For the professors, this experience meant enhancing personal global awareness, perspectives, and engagement; promoting new teaching strategies; integrating teaching with research and service; improvement in online and co-teaching skills; and experiential collaboration. For students, the international online experience offered the opportunity to build diverse personal relationships; offered a motivation to travel and study abroad as the relationships growth even outside the classroom; and most importantly, the development to intercultural awareness, online intercultural communicative competence, digital literacies, and working effectively in virtual teams.

\section{Recommendations}

Based on our observations and students' feedback, we offer the following comments and recommendations. Firstly, the instructors strongly support the inclusion of an international online experience in a course to: (1) internationalize the curriculum, and (2) enhance students' global competencies. This commitment drives the instructors selfassessment and recommendations for the upcoming offering of the second international online experience course:

1- Allow more time to students to get to know each other.

2- Provide to US and Mexico students a brief cultural introduction of each nation.

3- Decrease the number of students per group.

4- Monitor group members' participations.

5- Remaining flexible, though is best recommendation. As the international learning experience starts, the instructors will remain flexible - like in any other learning environment - to unforeseen challenges.

6- Incorporate more Mexican readings.

7- Incorporate Harvard's Project Zero Thinking Routines such as the Claim/Support/Question reasoning routine. 


\section{References}

ABDULLAHI, S. Rethinking global education in the twenty-first century. In: ZAJDA J. (Ed.). Global pedagogies: schooling for the future, p. 23-34. Dordrecht, New York: Springer, 2010.

ALTBACH, P.; KNIGHT, J. The internationalization of higher education: motivations and realities. Journal of Studies in International Education. v.11, n.3-4, p. 290-305. 2007. <http://dx.doi.org/10.1177/1028315307303542>. Accessed Fev16 2018.

BOIX-MANSILLA, V. How to be a GLOBAL THINKER. Educational Leadership, v.74, n.4, p.10-16. 2016.

BOIX-MANSILLA, V.; JACKSON, A. Educating for Global Competence: Preparing Our Youth to Engage the World. Retrieved from: <https://www.asiasociety.org/files/bookglobalcompetence.pdf>. 2011. Accessed Jan08.2018.

CANTO, S.; JAUREGI, K.; VAN DEN BERGH, H. Integrating cross-cultural interaction through video-communication and virtual worlds in foreign language teaching programs: Is there an added value? ReCALL. v.25, n.1, p.105-121. 2013. <http://dx.doi.org/10.1017/S0958344012000274> Accessed Fev17. 2018.

CAPDEFERRO, N.; ROMERO, M. Are online learners frustrated with collaborative learning experiences? The International Review of Research in Open and Distance Learning. v.13, n.2, p.26-44. 2012. Retrieved from <http://www.irrodl.org/index.php/irrodl/article/view/1127>. Accessed Mar12 2018.

CHEN, S.; CAROPRESO, E.; HSU, C.; YANG, J. Cross-cultural collaborative online learning: If you build it, will they come? Global Partners in Education Journal. v.2, n.1, p. 25-4. 2012.

IUSPA, F. Assessing a Historically Hispanic Serving Institution Internationalization Process. Sage Open. v.4, n.3. Jul-Sep 2014. <http://dx.doi.org/10.1177/2158244014552427> Accessed Fev14 2018. 
LANDORF, H.; DOSCHER, S.P. Defining global learning at Florida International University. Diversity \& Democracy. v. 18, n.3, p. 24-25. 2015.

LAW, E.; NGUYEN-NGOC, A. Analysis of cross-cultural online collaborative learning with social software. Interactive Technology and Smart Education. v. 7, n.4, p.247-263. 2010. < http://dx.doi.org/10.1108/17415651011096058>. Accessed Mar21 2018.

OECD. Global Competency for an Inclusive World. Retrieved from: $<$ https://www.oecd.org/education/Global-competency-for-an-inclusiveworld.pdfhttps://www.oecd.org/education/Global-competency-for-an-inclusiveworld.pdf>. 2016. Accessed Mar21 2018.

Partnership for 21st Century Learning. Framework for State Action on Global Education. Retrieved online: <http://www.p21.org/storage/documents/Global_Education/P21_State_Framework_on _Global_Education_New_Logo.pdf>.2014. Accessed Fev06 2018.

PIKE, G.; SELBY, D. Reconnecting: From national to global curriculum. Toronto, Canada: World Wide Fund \& International Institution for Global Education, 1995.

REIMERS, F.; CHOPRA, V.; CHUNG, C.; HIGDON, J.; O'DONNELL, E. Empowering Global Citizens: A World Course. North Charleston; North Carolina: CreateSpace Independent Publishing, 2016.

SUNY, Collaborative Online International Learning. Guide for Collaborative Online International Learning: Course Development. State University of New York: New York, 2017.

YANG, J.; HUIJU, Y.; CEN, S.-J.; HUANG, R. Strategies for Smooth and Effective CrossCultural Online Collaborative Learning. Educational Technology \& Society. v.17, n.3, p. 208-221. 2014.

recebido em 10 julho 2018 / aprovado em 22 outubro 2018

Para referenciar este texto:

IUSPA, F. Infusing an international online learning experience into the curriculum: a United States and Mexico collaboration. Dialogia, São Paulo, n. 30, p. 85-100, set. /dez. 2018. Disponível em: <https://doi.org/10.5585/Dialogia.n30.10774 